\title{
DETECTION OF NEWCASTLE DISEASES ANTIBODIES IN BIRDS IN JOS, BUKURU AND ENVIRONS USING AGAR-GEL PRECIPITATION TEST
}

\author{
A. S. Buru ${ }^{1 *}$, G. O. N. Echeonwu ${ }^{2}$ and A. E. J. Okwori ${ }^{3}$ \\ ${ }^{1}$ Ambrose Alli University, Ekpoma, Edo State, Nigeria, ${ }^{2}$ Virology Department, ${ }^{3}$ Microbiology Department, \\ Federal College of Veterinary and Medical Laboratory Technology, National Veterinary Research Institute, \\ P.M.B, 001 Vom, Plateau State, Nigeria
}

\begin{abstract}
Newcastle Disease Virus (NDV lasota) antibodies were surveyed. A serological study of 500 sera from local chicken, turkey, ducks and guinea fowl was carried out to determine the prevalence of Newcastle disease using Agar-gel precipitation technique. Samples were obtained from chickens slaughtered in Jos, Bukuru and environs. The samples were made up of 40 ducks, 50 turkeys, 20 guinea fowl and 390 local chickens. The precipitin antibodies were detected in ducks $7(17.5 \%)$, turkey $12(24.0 \%)$, guinea fowl $3(15.0 \%)$, and local chickens $54(13.9 \%)$. Of the 500 samples screened, a total of $76(15.2 \%)$ were positive for NDV antibodies. Quantitative analysis of sero-positive samples in the four avian species tested yielded a range of antibody titres of 2-16. The importance of using cost effective technique for the detection of NDV carrier state in local birds has been highlighted.
\end{abstract}

Keywords: NDV antibodies, Agar-gel precipitation technique (AGPT), NDV carrier state

\section{INTRODUCTION}

Newcastle disease (ND) is an acute, rapidly spreading, contagious, nervous and respiratory disease of birds of all ages caused by the avian Paramyxovirus serotype 1 (APMV-1) (Okeke and Lamorde, 1988). Transmission of the virus is most common through bird to bird contacts (Hugh-Jones et al., 1973), faecal exposure, respiratory discharges or other discharges from infected birds and through contact with contaminated feeds, water, equipment, poultry attendants and clothing, leading to high morbidity and mortality (Oladele et al., 2003; Saidu et al., 2006). ND is a major viral disease of economic significance in poultry (Anosa and Adene, 2007) and ranked as one of the chief constraints to the development of rural poultry production in Nigeria and in most developing countries, triggering serious dangers and concerns (Shamaki et al., 1989; Oladele et al., 2003). The disease is most common during harmattan period of the year (Alexander, 1997) and occurs in domestic fowls, exotic birds, turkeys, ducks, geese, pigeons and wild birds (Roy and Chamham, 2007; Echeonwu et al., 1993). It is characterized by nasal and ocular discharge, yellowish to greenish diarrhea, sneezing, coughing, drooping of wings, twisting of head, drop in egg production and thin shelled eggs, complete paralysis, weakness and sudden death (Chansiripomchai and Sasipreyayan, 2006; Roy and Chamham, 2007). Domestic chicken have been known to be sources of the spread of ND virus (Lancaster, 1963; Roy et al., 1998). Alexander et al. (1984) reported that the spread of ND virus to chickens has occurred in several countries, including Great Britain, where 20 out breaks in unvaccinated chickens occurred in 1984 through feed contaminated by faeces of infected pigeons. In rural Nigeria, it is common sight to find a combination of different poultry species and breeds together in the same compound (Ibrahim and Abdu, 1992), including chickens, turkeys, ducks and pigeons. Presently, it is accustomed to find ostriches, peacocks, geese and ducks in the same compound in cities and in some poultry farms. ND was reported in Nigeria in guinea fowls and a highly velogenic strain of ND virus was isolated from seemingly healthy ducks (Echeonwu et al., 1993). Outbreak of ND in young ostrich was also reported by (Saidu et al., 1999). There is only one serological evidence of ND infection in pigeons in Nigeria (Oladele et al., 1996). Therefore, validating a simple, cost effective technique for the detection of NDV carrier states in field bird in a limited resource setting cannot be underscored.

\section{MATERIALS AND METHODS \\ Collection of blood samples}

A total of five hundred (500) blood samples between April, 2005 and August, 2005 were collected from local birds such as local chickens, guinea fowls, turkey and ducks from Jos, Bukuru and environs slaughter houses into sterile McCarthney bottles. None of the birds were vaccinated against ND. The blood samples were made up of 390 local chickens, 20 guinea fowl, 40 ducks and 50 turkeys as shown in Table 1. The bottles were kept in a slanting position for the blood to clot and transported immediately to the laboratory.

*Corresponding e-mail address: asburu2002@yahoo.com 


\section{A. S. Buru and others}

The samples were left overnight at $4^{\circ} \mathrm{C}$, the serum were neatly collected by aspirating into bijou bottles and cryovials, labeled and stored in a freezer at $-20^{\circ} \mathrm{C}$ until required.

Antigen (NDV Lasota)

The NDV lasota antigen was used as a positive control for this research in the form of freeze-dried vaccine supplied by the National Veterinary Research Institute (NVRI) in Vom, Nigeria.

\section{Preparation of $0.7 \%$ Agar-gel}

The purified agar was used, it was prepared by weighing $8 \mathrm{~g}$ of Nacl and Agar $0.7 \mathrm{~g}$ into sterile $250 \mathrm{ml} \mathrm{Scott}$ bottle and the volume was made to $100 \mathrm{ml}$ with distilled water and mixed properly. The preparation was autoclaved at $121^{\circ} \mathrm{C}$ for fifteen (15) minutes to dissolve the agar. The agar was allowed to cool to about $45^{\circ} \mathrm{C}$ and then poured into sterile petri dishes, arranged on a flat surface; plates were covered and left at room temperature for agar to set. The agar plate were stored at $4^{\circ} \mathrm{C}$ refrigerator and used within seven days of preparation.

\section{Agar-gel precipitation test (AGPT)}

The Qualitative and Quantitative agar-gel precipitin test has been used for the detection of antibodies in poultry virus (Witter, 1972; Baron, 1991). Two fold serial dilution of 1:2, 1:4, 1:8, 1:16, 1:32, 1:64, 1:128 and 1:256 of all test sera were prepared using sterile phosphate buffered saline (PBS) as diluent.

\section{RESULTS AND DISCUSSION}

Out of 500 samples, $76(15.2 \%)$ were positive and $424(84.8 \%)$ were negative for Newcastle disease virus antibodies. The highest overall prevalence of ND was found in turkey (24.0\%) (Table 2).

Table 1. Number of blood samples used in this study

\begin{tabular}{|lccccc|}
\hline Sources & Chicken & G/F & Ducks & Turkey & Total \\
\hline Bukuru slaughter market & 230 & 13 & 27 & 30 & 300 \\
Jos slaughter market & 160 & 87 & 13 & 20 & 20 \\
\hline Total & 390 & 20 & 40 & 50 & 500 \\
\hline
\end{tabular}

Table 2. Distribution of NDV (lasota) antibodies detected in the 4 avian species sampled

\begin{tabular}{|lccc|}
\hline Types of Birds & Number sampled & Number positive & Prevalence (\%) \\
\hline Ducks & 40 & 7 & 17.5 \\
Turkeys & 50 & 12 & 24.0 \\
Guinea fowl & 20 & 3 & 15.0 \\
Local chicken & 390 & 54 & 13.9 \\
\hline Total & 500 & 76 & 15.2 \\
\hline
\end{tabular}

With recent surge of incidence of different strains of avian influenza virus, the quest for developing and validating already existing methods that are cost effective, fast turnaround time and easy to handle cannot be underscore. From the result of qualitative analysis, a total prevalence of $15.2 \%$ (76) positive agar-gel precipitin antibody reaction to newcastle disease virus (lasota) was recorded among unvaccinated local birds (duck, turkey, guinea fowl $(\mathrm{G} / \mathrm{F})$ and chicken), this therefore, suggested that the presence of antibodies to Newcastle disease virus were due to exposure to the ND virus. The results of this present study as shown in table 2 indicate that there are significant activities of NDV (lasota) in local birds in Bukuru, Jos and environs. Since there is no vaccination programme for these local birds, presence of antibody in these apparently healthy local birds is an indication of sub-clinical infection and could act as a carriers of ND virus (Bell and Mouloudi, 1988; Olabode et al., 1992). Table 3 showed the significant varying titre reactivity of each avian species with turkey and local chicken having the highest titre of 8 and 16 respectively, while Table 4-7 showed the breakdown of the titration for each of the avian species that showed significant titre reactivity with local chicken and turkey showing the highest percentage of the number of the positive sera screened. 
Table 3. Quantitative analysis of sero-positive samples antibody range

\begin{tabular}{|lcccc|}
\hline Type of Birds & Number of positive & Line of precipitin & No line of precipitin & Titre \\
\hline Ducks & 7 & 2 & 5 & $2-4$ \\
Turkeys & 12 & 4 & 8 & $2-8$ \\
Guinea fowl & 3 & 1 & 2 & $2-4$ \\
Local chicken & 54 & 12 & 42 & $2-16$ \\
\hline
\end{tabular}

Table 4. Quantitative analysis of sero-positive samples: NDV antibody titres in ducks

\begin{tabular}{|ccc|}
\hline Antibody titre $(\log 2)$ & Number of positive & $(\%)$ positive \\
\hline 4 & 0 & 0.0 \\
3 & 0 & 0.0 \\
2 & 1 & 50.0 \\
1 & 1 & 50.0 \\
\hline
\end{tabular}

Table 5. Analysis of sero-positive samples NDV antibody titre in turkeys

\begin{tabular}{|ccc|}
\hline Antibody titre $(\log 2)$ & Number of positive & $(\%)$ positive \\
\hline 4 & 0 & 0.0 \\
3 & 2 & 50.0 \\
2 & 1 & 25.0 \\
1 & 1 & 25.0 \\
\hline
\end{tabular}

Table 6. Quantitative analysis sero-positive samples: NDV antibody in guinea fowl $(\mathrm{G} / \mathrm{F})$

\begin{tabular}{|ccc|}
\hline Antibody titre $(\log 2)$ & Number of positive & $(\%)$ positive \\
\hline 4 & 0 & 0 \\
3 & 0 & 0 \\
2 & 0 & 0 \\
1 & 1 & 100 \\
\hline
\end{tabular}

Table 7. Quantitative analysis sero-positive samples: NDV antibody in local chickens

\begin{tabular}{|ccc|}
\hline Antibody titre $(\log 2)$ & Number of positive & $(\%)$ positive \\
\hline 4 & 1 & 8.3 \\
3 & 5 & 41.7 \\
2 & 4 & 33.3 \\
1 & 2 & 16.7 \\
\hline
\end{tabular}

The findings of this study are similar to results of similar studies carried out by other authors (Iroegbu and Echeonwu, 1997; Mai et al., 2004; Musa et al., 2009; Nwanta et al., 2006). The qualitative analyses of the distribution of NDV antibodies in the 4 local birds gave a cogent breakdown of the prevalence of the ND virus amongst the 4 avian species with turkey having the highest prevalence. 


\section{A. S. Buru and others}

The NDV Agar-gel precipitation test (AGPT), will be greatly valuable in areas of the world where limited facilities or technical know-how is a challenge for using serological procedures. The susceptibility of local birds to ND virus in Nigeria is somewhat high and no matter the age of the birds if it remains unvaccinated it is still susceptible.

\section{CONCLUSION}

The AGPT has been found to be simple, inexpensive and faster in assessing ND infection in birds, though there are more sensitive techniques for the detecting of NDV but the AGPT method used for this research was easily available and affordable at the time and location. Education of farmers on good practice of poultry keeping should still be encourage to prevent spread of ND infection among other flock and this include proper handling and disposal of used litters, construction of bird and vermin prof houses and proper disinfection of poultry house time to time with suitable disinfectant as the virus can persist in the environment for a very long time.

\section{ACKNOWLEDGEMENT}

We wish to express our gratitude to the management of Federal College of Veterinary and Medical Laboratory Technology, Vom, Plateau State for the financial support to this project.

\section{REFERENCES}

1. Alexander DJ (1997). Newcastle Diseases and avian paramyxoviridae infection. In: Diseases of poultry, tenth edition, cabinet. BW Barnes, HJ Beard, CW McDougald, IR Saif YM. editors. Pp. 541-570.

2. Alexander DJ, Pearson G and Marshal R (1984). Infection of fowls with Newcastle disease virus by food contaminated with pigeon faeces. Veterinary Record 115: 601-602

3. Anosa GN and Adene DF (2007). Comparative tissue reactivity of lentogenic strains of Newcastle disease vaccines in Nigeria. Nigerian Veterinary Journal 28 (3): 6-10

4. Bell JG and Mouloudi S (1988). A reservoir of virulent Newcastle disease virus in village chicken flocks. Review of Veterinary Medicine 6: 37-42

5. Chansiripomchai N and Sasipreyayan J (2006). Efficacy of live B1 or Ulster 2c Newcastle disease vaccines simultaneously vaccinated with inactivated oil adjuvant vaccine for protection of Newcastle disease virus in broiler chickens. Acta Veterinaria Scandinavica 48: 1-4.

6. Echeonwu GON, Iroegbu CU and Emeruwa AC (1993). Recovery of velogenic Newcastle disease virus from dead and healthy free-roaming birds in Nigeria. Avian Pathology 22: 383-387.

7. Hugh-Jones ME, Allan WH, Dare FA and Harper GJ (1973). The evidence of airborne spread of Newcastle disease. Journal of Hygiene, Cambridge 71: 325-339

8. Ibrahim MA and Abdu PA (1992). Ethno agro-veterinary perspectives of poultry management, health and production among the Hausa/Fulani of rural Nigeria. Proceeding of the $29^{\text {th }}$ Annual General Meeting of Nigerian Veterinary Medical Association. $27^{\text {th }}-30^{\text {th }}$ October, Kaduna, Nigeria, pp. 172-181.

9. Iroegbu CU and Echeonwu GON (1997). Seroprevalence of Newcastle disease virus infection in the Nigerian local chicken population. Nigerian Journal of Micrbiology 11: $112-114$.

10. Lancaster JE (1963): Newcastle disease. Methods of spread. Veterinary Bulletin 83: 221-226.

11. Mai HM, Ogunsola OD and Obasi OL (2004). Serological Survey of the Newcastle disease and infections bursal Disease in Local ducks and local guinea fowls In Jos, Plateau State, Nigeria. Revue d'élevage et de médecine vétérinaire des pays tropicaux 57: 41-44.

12. Musa U, Abdu PA, Dafwang II, Umoh JU, Saidu L, Mera UM and Edache JA (2009). Seroprevalence, seasonal occurrence and clinical manifestation of Newcastle Disease in Rural Household Chickens in Plateau State, Nigeria. International Journal of Poultry Science 8(2): 200-2004.

13. Nwanta JAY, Umoh JU, Abdu PA, Ajogi I, Alli-Balogun JK (2006). Management of losses and Newcastle Disease in Rural Poultry in Kaduna State, Nigeria. Nigerian Journal of Animal Production 33(2): 274-285.

14. Okeke EN and Lamorde AG (1988). Newcastle disease and its control in Nigeria. In: A. Olufemi and W.N. Masiga, (Ed), Proceedings of an international Conference on Viral diseases of animals in Africa. Lagos, Nigeria, pp: 284-293 
15. Olabode AO, Shidali NN, Lamorde AG and Chukwuedo AA (1992). Newcastle disease in local chickens in Nigeria. ACIAR Proceedings of International Conference on Thermostable ND Vaccines and Control, held at kaula Lumpo, Malaysia.

16. Oladele SB, Abdu P, Esievo KAN, Nok AJ, Useh NM (2003). Prevalence of Newcastle Disease virus antibodies in chickens reared in Zaria. Proceedings of the 28th Annual conference Nigerian Society of Animal Production 28: 7-9.

17. Oladele SB, Kazeem HM, and Raji MA (1996). Survey for antibodies to infectious bursal disease, Newcastle disease and fowl pox in ducks, pigeons and guinea fowls in Zaria. Nigerian Veterinary Journal 1: 85-87.

18. Roy S and Chamham HVS (2007). Poultry disease diagnosis and treatment $3^{\text {rd }}$ edition pp: 56-62.

19. Roy P, Venugopalan AT and Manvell R (1998). Isolation of Newcastle disease virus from an Indian house crow. Tropical Animal Health and Production 30(3): 177-178.

20. Saidu L, Abdu PA, Hua ST, Oyelola K and Raji MA (1999). Suspected Newcastle and mycomycosis in a flock of seven-week-old ostrich. Zariya Veterinarian 6: 155-157.

21. Saidu L, Abdu PA, Tekdek LB, Umoh jU, Usman M, Oladele BS (2006). Newcastle disease in Nigeria, Nigerian Veterinary Journal 27(2): 23-32.

22. Shamaki D, Durojaiye OA and Ojeh CK (1989). The immunogenicity of Newcastle disease Vaccines used in Nigeria. Zariya Veterinarian 4: 19-24. 